\title{
SOCIAL MEDIA'S OFFICIAL DESTINATION PROMO VIDEOS AND COUNTRY IMAGE INFLUENCING VISITING INTENTION TO RISKY DESTINATIONS
}

\author{
Dyuty Firoz* \\ Research Scholar, Taylor's School of Business and Law \\ Taylor's University, No.1, Jalan Taylor's, 47500, Subang Jaya, Selangor, Malaysia.

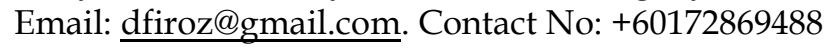 \\ Dr Saeed Pahlevan Sharif \\ Associate Professor, Head of Research \\ Taylor's School of Business and Law, Taylor's University, \\ No.1, Jalan Taylor's, 47500, Subang Jaya, Selangor, Malaysia. \\ Dr Nurlida Binti Ismail \\ Associate Professor, Taylor's School of Business and Law, Taylor's University, \\ No.1, Jalan Taylor's, 47500, Subang Jaya, Selangor, Malaysia.
}

\begin{abstract}
Social media destination promo videos (DPVs), are among the most important information sources of travel decision-making for their interactive and sharing features, and outstanding destinationpromotion strategy. Country image is also another important factor for travel decision-making. This study's purpose is to assess whether the social media DPVs like DMOs' promo videos and country image, have any impact on visiting intentions towards risky destination. Quantitative method was used for this study. Data was collected by online questionnaires, and 609 valid responses were considered for the analysis of the study. The results showed that the country image positively influences attitude of young tourists towards the country, and that attention towards the promo videos positively influences young tourists' overall emotions, attitudes, social-norms, interests, desires and behaviours toward visiting a risky destination. This study results would be beneficial for those who are interested in using social media DPVs as part of their destination-promotion strategy, and also can guide destination-marketers to monitor and create better destination promotional contents in social media platforms, to encourage tourism to the destinations, especially risky ones.
\end{abstract}

Keywords: social-media; destination-promo-videos; risky-destination; country-image; traveldecision-making; integrated-model.

\section{INTRODUCTION}

Social media platform became a significant promotion means for promoting destination (Uşaklı et. al., 2017), and the primary preference of destination marketing organizations (DMOs) to create a destination's brand page (Kumar, Mishra \& Rao, 2021). It is the popular resources of retrieving online information related to travel (Barcelos, Dantas \& Sénécal, 2019), and concurrently gives platform to influencers and tourists to present their own views regarding a destination or country (Tiago et al., 2019). In any destination marketing, whether online or offline, country image is the main factor, and also for prospective tourists to select for visiting, and eventually make it a necessary segment for assessment in tourism studies (Assante et al.,
2014). Country image significance while selecting a place of travelling, unquestionably depends on the tourist's positive view of that country, and is considered more than a negative-imaged country, in destinationselection process (Zhang et al., 2018).

Risky destination is becoming an appreciated subject among researchers and DMOs in the past few years, due to continuing calamities and dangerous events, like warfare, terroristattacks, natural calamities, political conflict, pandemics, etc. (Alvarez \& Campo, 2014), effecting the country images and tourism industry globally. Most of the tourists would not think to visit these countries, with the mentioned risks, in the first place (Dolnicar \& Hajibaba, 2015), and would tend to avoid 
(Neuburger \& Egger, 2021), because safety and security always become the first priority while travelling (Hajibaba et al., 2015). For this, tourists' rates are declining in these countries and economies are gradually becoming unstable (Ibrahim, 2015). Therefore, more detailed researches are required on country image segment and promotion strategies to improve their images, influence prospective tourist's decision-making and make these countries' tourism sector become flourished again. Hence became a scope of research for this study. Destination promo videos (DPVs) could be one of the strategies that can alter tourists' view of the destination and can create a positive image in mind (Yanjun et al., 2014). It is seen that DMOs' or official DPVs (ODPV) became a popular method to attract tourists' attention and influence their visiting intentions (Fong, Firoz, \& Sulaiman, 2018; Brodien Hapairai et al., 2018), and exhibited contributions in the development of tourism segments of the respective countries (Chen et al., 2010; Lee, Pan \& Tsai, 2011). However, very few studies were conducted on the decision-making influence (Chen et al., 2010; Gong \& Tung, 2017), hence became a research gap for this study.

The main objective of the research was to assess online ODPV and country image influence over attitude towards the destination, and visit decision-making behaviors towards risky destination. Egypt was chosen to be the risky destination for this study, because, being considered to be one of the most beautiful heritage tourism destination, the negative occurrences like, political-instabilities, terrorism-attacks, pandemics and the uncertainties of getting impacted by them, affected the travel and tourism economy, and declined their GDP (WTTC, 2018).

\section{LITERATURE REVIEW}

2.1 Country Image - Its Importance, Influence and Risks

Country image is defined by Alvarez \& Martínez (2010) as "the sum of beliefs and impressions people hold about places". It focuses on the way image of the country affects customer's view and attitude towards that country's people, the place, and their market contributions (Lu et al., 2016). Country image is often studied by either its cognitive or its affective components only (Alvarez \&
Campo, 2014; Wang et al., 2012) or both (Hendriana, Awang, \& Yusof, 2021; Lindblom et al., 2018; Wang, 2020). Cognitive country image refers to quality of life, financial status, technology level, and literacy level related to the place, and affective country image refers to friendly, pleasant, safe, and trustworthy, prospect of the place (Elliot et al., 2011; Maher \& Carter, 2011).

There are very few researches on promoting risky destinations (Syafganti, \& Walrave, 2019; Walters, \& Beirman, 2017). It is seen that effective communication strategies helped to renew a damaged brand (Andrews \& Kim, 2007). Keeping this fact in mind, all countries' DMOs, find and create effective strategies or factors of promoting destinations, and ways to make their destinations, especially risky ones, more attractive and safer, to potential tourists (Alvarez \& Campo, 2014). Hence more studies are required on destination promotion strategies, country image and visit decisionmaking behaviour towards these risky destinations.

1.2 Attitude towards the destination intend to visit In a tourism context, attitude towards the destination is a psychological tendency of tourists which is showed as positive or negative evaluations, when carrying out a specific behavior (Ajzen, 1991). Attitude consists of behavioral, cognitive and affective factors. Cognitive factor is the assessment made in forming attitude, the affective factor refers to the mental reaction conveying the destination preference, and the behavioral factor is the verbal sign of visit intention (Unger \& Wandermann, 1985, as cited in Itoo \& Nagar, 2017). These factors' integrations, somehow resembles the formation of country image: "the image of this country is formed mainly through its affective component and through its cognitive one" (Alvarez \& Campo, 2014).

For deciding to visit a particular place, attitude of a tourist is a good forecaster of their decision-making process (Li, Cai, \& Qiu, 2016). Existing literature show that a destination in media like films, videos, etc., significantly enriched the attitude toward it, because it increases the destination-familiarity (Hede, 2005, as cited in Itoo \& Nagar, 2017), and inspires their visit intention (Kim \& Richardson, 2003). Positive destination 
elements form a good destination attitude, while negative elements might create the opposite (Della Corte, 2000, as cited in Itoo, \& Nagar, 2019). Studies related to attitudes towards the destination, in respect to country image, have not been explored in much details, thus becoming a research gap for this study.

\section{THEORETICAL FRAMEWORK - RESEARCH MODEL DEVELOPMENT}

AIDA (Attention, Interest, Desire and Action) is a popular and effective model to find out the viewers' relation with any advertisement media till their final behaviour, like buying or visiting, and also the advertisement efficiency (Hyder, et al. 2014). However, in tourism literatures, there are very few studies conducted using AIDA model (Hudson, Wang, \& Gil 2011; Fong, Firoz, \& Sulaiman, 2018; Lee et al., 2018) and portrayed its efficacy. After seeing successful utilization of AIDA in previous tourism literatures, this study used AIDA model in destination marketing context.

Model of goal-directed behavior (MGB) have proven to be also a popular and efficient model for predicting and assessing complex decision-making processes and future behavioral intention (Park, Lee, \& Peters, 2017; Lee et al., 2018). It incorporates desire factor with attitudes, subjective norms, and perceived behavior control, the main elements of decision-making in the theory of planned behavoir (TPB), which motivates a person's mind to behavioral intention (Perugini \& Conner, 2000). It also adds in positive and negative anticipated emotions (PAE/NAE) which affirms the emotional concerns to stimulate the desire in finalizing a person's success or failure, in attaining a particular behavioral intent (Song et al., 2014), and can foresee the decision-making behavior (Han \& Yoon, 2015). It is also seen that extended MGB models (EMGBs) improved assessment of decision-making behavioral intention (Park, Lee, \& Peters, 2017; Kim Lee, \& Kim, 2021). This study employed the adapted integrated model of AIDA and MGB from Lee et al. (2018) study, as because it was proven to be a good framework that can assess more complex decision-making processes related to media effects. In recent years, media are playing a great role in tourism promotion of many countries (Pennacchia, 2015). In a way it can be said media aided in creating a countryinterest, formed a visit-desire, and conclusively leading to the country-visit intention. These gradual segments is elucidated by AIDA model.

Tourists form emotional ties between themselves and the places through various forms of media (Zeng et al. 2015), and becomes emotionally engaged and invested means (Gray, Sandvoss, \& Harrington, 2007).

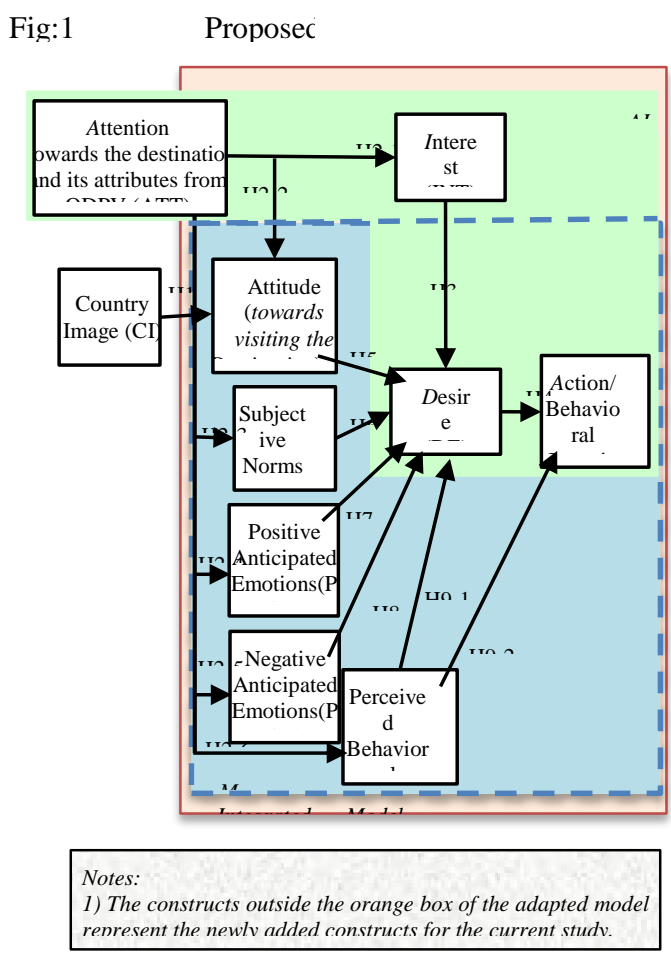

High emotionally-attached viewers towards media programs are more likely to visit those particular places seen in the media (Kim, 2012). Such results propose that emotion is avital element in cognizing the procedures for making decision, after viewing any media. As stated in section 3.2, MGB is known as a good model for assessing complex decision-making processes and visiting intention, and moreover, the conceptions of MGB's desires and behavioral intentions are shared in common with AIDA's desires and Action. This proposed the possible prospect to employ the adapted integrated model to assess the prospective tourists' decision-making processes after media viewing. Country image construct was added in the adapted integrated model through MGB, making it an extended integrated model of AIDA and MGB. Figure 1 shows the proposed research model.

\subsection{Hypothesis development}


Country image impacts customers' attitudes toward the products through their inferable beliefs and viewpoints about the specific country (Laroche et al., 2005). It was studied in both cognitive and affective segments in several researches (Hendriana, Awang, \& Yusof, 2021; Lindblom, et al., 2018; Wang, 2020). Philip et al. (2013) tested a model where the country's cognitive image influenced its affective image, and, implicitly, on the attitude towards having Korean food. Prospective tourists can form favourable attitudes toward a destination with sufficient positive attributes (Della Corte, 2000, as cited in Itoo, \& Nagar, 2019). This concept relating to country image, in tourism context, is still at early stage of study, especially in respect to a risky destination. Hence the following hypothesis was proposed:

H1: Country's Image of the risky place significantly effects the attitude towards visiting the place.

The emotional images of a place in any media, strongly create attraction and attention towards it (Zeng et al, 2015), and interest to visit (Tham, \& Kim, 2018; Sousa, \& Silva, 2018). It is seen that the DPVs can trigger the interest of visiting a place through their video contents (Fong, Firoz, \& Sulaiman, 2018), by forming an attraction and attention towards it. So, this study assumed that online ODPVs could attract young tourist's attention to places through their contents, which inspires their intention or interests them in visiting the destination shown. For example, people who are fond of Korean pop culture, and watched their films, drama, songs, etc., get to know the products, places, people and many more, and boosted their interest in visiting Korea (Lee et al., 2018). So, it can be presumed that people learn more about destination attributes through media, and make them more interested in visiting that place. Hence, the following hypothesis was proposed:

H2-1: Attention towards the destination and its attributes in the promo video significantly effects the interest in the place.

Studies show that ODPV can influence young tourists' behaviors and attitudes regarding travelling to the places (Karyotakis et al. 2018). Attention towards UGC contents like DPV (Shani et al., 2010) can form tourist's attitudes, belief, feelings or emotions, regarding travelling to a destination. It seen that travel-related videos can influence a visitor regarding visiting a destination, emotionally, and can create powerful emotions between the tourists and the destinations viewed in the videos (Huertas et al., 2017). However, studies related to online DPVs and the emotional relationship with them, hasn't been conducted yet in details. There is a relation between liking a video and feeling positive emotions, and if any negative emotions created, then both are omitted (Teixeira, 2017). In social media, Taylor et al., (2011) found a positive relation within advertisement and customers' attitudes. However, studies related to the influence of attention towards the destination and its attributes in ODPVs, on visit intention decision-making process, has not been studied yet in detail. Hence, this study anticipated the following hypotheses:

Attention towards the destination and its attributes in the promo video significantly effects: (H2-2) attitudes (towards the destination); (H2-3) subjective norms; (H2-4) positive anticipated emotions; (H2-5) negative anticipated emotions; (H2-6) perceived behavioral control.

Desire, the third level of AIDA model (Rawal, 2013), is a vital successor of the interest factor. When a video portrays contents of interest regarding a destination, it's easier to create a desire to visit the place (Teixeira, 2017). Hudson, Wang, \& Gil (2011) found that viewers' interests created by a film, Motorcycle Diaries (based on South America), formed higher desires to visit the countries shown in the film. In the study by Lee et al. (2018), tourists' interest in the destination or country formed a strong desire in visiting the pop-cultured destination. However, interest towards a risky destination creating a desire to visit, has not been tested yet, and hence anticipated the following hypothesis:

H3: Interest in the country significantly effects desire to travel.

Desire is the psychological power that guides to complete a behavioral intention or action (Wijaya, 2015). Action is the last stage in the AIDA model where customers make a final decision regarding a product or service and take a behavioral action, like buying (Rawal, 2013). Desire positively influences behavioral intents to visit pop-culture destinations (Lee et al., 2018). As desire is taken as the main factor of behavioral intention of any action and is an 
essential factor in making future visit decisionmaking (Lee et al., 2018), it might influence behavioral intents to visit risky destinations too, and hence anticipated the following hypothesis:

H4: Desire to visit significantly influences behavioral intention.

Attitude lead to desire, and desire leads to behavioral intents (Song et al., 2012), and significantly relates with desire in visiting a pop-cultured destination Lee et al., (2018). Lee et al., (2020) stated that attitude have positive influence on desire toward heritage tourism destinations visiting, and Meng and Choi (2016) stated that attitude have negative effects on desire toward partaking in slow tourism. Hence, to analyze the influence of attitude in desire to travel to a risky place, anticipated the following hypothesis:

H5: Attitude towards the destination significantly influences desire to visit.

Subjective norms (SN) refer to the social anxiety perceptions that make a person to participate in an activity (Ajzen, 1991), and is an important construct in creating desire (Song et al., 2012). Some researchers have showed $\mathrm{SN}$ to be an important desire's predecessor (Carrus et al., 2008; Prestwich, et al., 2008). It relates with desire in forming a visiting intention to popcultured destination (Lee et al., 2018). SN were found to play significant roles in forming tourists' desire visit popular destinations (Meng \& Choi, 2016; Lee et al., 2018, 2020). Hence, in risky destination perspective, the following hypothesis was proposed:

H6: Subjective norms significantly influences desire to visit.

Positive anticipated emotions (PAE) and negative anticipated emotions (NAE) perform significant parts in forming tourists' desire to travel to places (Lee et al., 2018). PAE portray a positive feeling and possess a solid positive response and NAE portray a negative feeling, which might rise when a person cannot achieve a desired goal (Perugini \& Bagozzi, 2001), and forms desire to take part in responsible tourism (Kim, Lee \& Fairhust, 2017). Studies have explored the relationship between PAE, NAE and desire by using MGB (e.g., Lee et al., 2018; 2020). For instance, Song et al., (2014) stated that PAE and NAE positively effect desire in the case of visa exemption. Both of these emotions play an important part in creating desires to attain an aim (Song et al., 2012). Focusing on this, and in respect towards risky destinations, this research study anticipated the following hypotheses:

H7: Positive anticipated emotions significantly influence desire to visit.

H8: Negative anticipated emotions significantly influence desire to visit.

A person's capability/self-confidence to perform a behavior for achieving a specific aim usually explained as perceived behavioral control (PBC) (Ajzen 1991). Previous studies showed significant influence of $\mathrm{PBC}$ on both desire and behavioral intention (Leone, Perugini, \& Ercolani 2004; Carrus, Passafaro, \& Bonnes 2008). In MGB, some studies showed that PBC strongly affects a person's decisionmaking, which portrays his/her ability to complete a behavioral intention (Lee et al., 2012; Song et. al., 2014). In hospitality and tourism segment, Yi, Yuan \& Yoo (2020), found PBC to be positively relates with desire for using Airbnb, and Meng and Choi (2016) found negatively effecting desire in slow tourism context. PBC plays important part in forming tourists' desire to pop-culture and popular tourism destination (Lee et al., 2018, 2020). Moreover, $\mathrm{PBC}$ also positively relates with the inspire to accomplish the certain behavioral intent (Gstaettner, Rodger \& Lee, 2017). However, in risky destination context, the literatures are still at early stage, and hence anticipated the following hypotheses:

H9-1: Perceived behavioral control significantly influences desire to visit.

H9-2: Perceived behavioral control significantly influences behavioral intention.

\section{METHOD}

4.1 Measurement Items and Scales

All the variables' measurement items, excluding attention towards the destination and its attributes from ODPV (ATT), attitude towards the destination (AT), and country image $(\mathrm{CI})$, contained four items and were adapted from study by Lee et al., (2018). CI measurement items was adapted from Campo and Alvarez (2010) and Lee et al., (2018) studies. AT consists of six measurement items, and are adapted from Huang \& Hsu (2009) and Huang \& Veen (2018) studies. There are few studies where 
ATT had four items for measuring it (Lee et al., 2018; Song et al., 2021). However, those measurements did not focus on measuring ODPV in particular. Moreover, a more detailed measures of attention was required to understand their attention elements from the ODPV's destination attributes displayed and what actually was grabbing the attention towards that destination in the promo video along with some pre-knowledge regarding the place, which is a very important term for this study. That is why, attention measurement items were constructed by conducting online open-ended interview and face-to-face interview with postgraduate students who volunteered for this, instead of adapting from previous literatures.

First, an overview of the objectives and aims of the study were provided to the participants and were informed and made sure of the protection of their privacy and anonymity. Then, all the participants were asked to list what attracts and catch attention when they think about Egypt (the country chosen for this study) when they viewed the Egypt's ODPV (ODPV chosen for this study), and what they would like to do if they visit Egypt. They were also asked about what other destination attributes of Egypt attracts them, other than the video. Focusing on the commonality of the answers, a total of 15 students' answers, including 6 males and 9 females were considered. All the participants knew Egypt. A total of 10 main destination attributes and activities that attract people towards Egypt from the video and the country itself, were achieved. For example, pyramids and hot deserts, desert safari and pharaoh mummies in museums, Nile cruises and yachts, night market, people, culture, Arabic food and many more. The selected items were then evaluated by three academic experts in the related fields. A 7-point likert scale were used for all the measurement items of the above-mentioned constructs, including the constructed one, denoting 1 for "Strongly disagree" to 7 denoting "Strongly Agree".

\subsection{Sample and Data collection}

For this study, young tourists of Malaysia, despite of their country of origin, were chosen for the convenience of the study; for risky destination, Egypt was chosen; and for the ODPV, the country's award-winning ODPV "This Is Egypt", was chosen. This ODPV defeated 63 other contestants in the competition which took place at the General Assembly of the World Tourism Organization (WTO) in China, in 2017 (UNTWO, 2018).

Table 1: Demographic Profile of Respondents

\begin{tabular}{|c|c|c|c|}
\hline & Category & Frequency & Percentage (\%) \\
\hline \multirow[t]{2}{*}{ Gender } & Male & 228 & 36.44 \\
\hline & Female & 381 & 62.56 \\
\hline \multirow[t]{4}{*}{ Age group } & $18-20$ & 205 & 33.66 \\
\hline & $21-23$ & 322 & 52.87 \\
\hline & $24-26$ & 53 & 8.7 \\
\hline & Above 27 & 35 & 4.30 \\
\hline Total & & 609 & 100 \\
\hline \multirow[t]{7}{*}{ Education level } & Cambridge GCSE A level & 2 & 0.33 \\
\hline & Foundation & 7 & 1.15 \\
\hline & Diploma & 12 & 1.97 \\
\hline & Bachelor's & 542 & 89 \\
\hline & Masters & 21 & 3.45 \\
\hline & $\mathrm{PhD}$ & 24 & 3.94 \\
\hline & Others: ICAEW & 1 & 0.16 \\
\hline \multirow{2}{*}{$\begin{array}{l}\text { Country of Origin/ } \\
\text { Nationality }\end{array}$} & Malaysian & 437 & 71.76 \\
\hline & Non-Malaysian & 173 & 28.24 \\
\hline Total & & 609 & 100 \\
\hline
\end{tabular}


Due the current pandemic situation, emails and social networking applications like LinkedIn and WhatsApp, were viable choice of collecting data, so that the respondents can easily access and answer in their convenient times safely. Convenience and snowballing sampling were used. A total of 721 responses were collected through self-administered online questionnaires, and only 609 responses were found to be useful for the study. SPSS and PLS-SEM were considered to be the best statistical tools for conducting data analysis for this study and IBM SPSS 26 and SMART PLS 3.3.2 software were used.

\section{ANALYSIS}

The demographic profile, showed in Table 1, portrayed that, female respondents were $62.56 \%$ followed by male respondents, $36.44 \%$, and around $52.87 \%$ were in between 21-23 years, and $33.66 \%$ were in between 1820 years. The constructs in the measurement model are fairly symmetrical with skewness level starting from -0.577 to -0.036 . The kurtosis values are within normal range with a flatter scale distribution. BI's mean, which is 4.647 with 1.513 standard deviation, portrayed that almost all the respondents accepted that this is an important outcome of the study.

The corresponding variables and loadings, portrayed in Table 2, are within 0.606 and 0.943. Accordingly, the composite reliability (CR) values are within 0.799 and 0.969 , hence exceeding the cut-off value, 0.70 , according to Hair et al., (2017). Average variance extracted (AVE) also were more than the cut-off value, 0.50 (Fornell \& Larcker, 1981). All values of Cronbach's alpha are more than the cut-off value, 0.70 (Nunnally \& Bernstein, 1994). Thus, all the research model's variables have satisfactory convergent validity and a good internal consistency reliability.

Table 2: The measurement model's constructs' Confirmatory factor analysis, reliability and convergent validity

\begin{tabular}{|c|c|c|c|c|c|c|c|c|}
\hline Construct & Mean & $\begin{array}{c}\text { Standard } \\
\text { Deviation }\end{array}$ & $\begin{array}{l}\text { Excess } \\
\text { Kurtosis }\end{array}$ & Skewness & Loading & $\begin{array}{c}\text { Cronbach's } \\
\text { Alpha }\end{array}$ & CR & AVE \\
\hline \multicolumn{9}{|l|}{ Country Image (CI) } \\
\hline Egypt is a pleasant country. & 5.161 & 1.119 & -0.552 & 0.136 & 0.767 & \multirow[t]{12}{*}{0.937} & \multirow[t]{12}{*}{0.945} & \multirow[t]{12}{*}{0.592} \\
\hline Egypt people are friendly. & 4.778 & 1.256 & -0.110 & -0.200 & 0.778 & & & \\
\hline Egypt is safe. & 4.348 & 1.001 & -0.019 & -0.139 & 0.813 & & & \\
\hline $\begin{array}{l}\text { Egypt people are } \\
\text { trustworthy. }\end{array}$ & 4.435 & 0.976 & -1.009 & 0.225 & 0.817 & & & \\
\hline Egypt arouses good feeling & 4.841 & 1.277 & -0.946 & 0.231 & 0.775 & & & \\
\hline $\begin{array}{l}\text { Egypt is a good reputed } \\
\text { country. }\end{array}$ & 4.581 & 0.996 & -1.072 & -0.005 & 0.792 & & & \\
\hline Egypt is a secure country & 4.259 & 0.988 & -0.884 & 0.362 & 0.840 & & & \\
\hline Egypt is a peaceful country & 4.337 & 0.973 & -0.882 & 0.294 & 0.803 & & & \\
\hline Egypt has a high level of life & 4.404 & 1.029 & -1.110 & 0.164 & 0.773 & & & \\
\hline $\begin{array}{l}\text { Egypt has a high level of } \\
\text { literacy }\end{array}$ & 4.539 & 0.969 & -0.995 & 0.108 & 0.683 & & & \\
\hline $\begin{array}{l}\text { Egypt is a technologically } \\
\text { developed country }\end{array}$ & 4.167 & 1.283 & 0.140 & 0.017 & 0.687 & & & \\
\hline $\begin{array}{l}\text { Egypt has high level of } \\
\text { wealth }\end{array}$ & 4.545 & 1.050 & -1.203 & 0.008 & 0.682 & & & \\
\hline \multicolumn{9}{|l|}{$\begin{array}{l}\text { Attention Towards the } \\
\text { destination (ATT) }\end{array}$} \\
\hline $\begin{array}{l}\text { Egypt's pyramids in the } \\
\text { video grab my interest. }\end{array}$ & 6.338 & 0.805 & -1.120 & -0.688 & 0.710 & \multirow[t]{6}{*}{0.893} & \multirow[t]{6}{*}{0.913} & \multirow[t]{6}{*}{0.514} \\
\hline $\begin{array}{l}\text { Hot deserts of Egypt in the } \\
\text { video catch my attention. }\end{array}$ & 5.141 & 1.713 & -0.365 & -0.752 & 0.594 & & & \\
\hline $\begin{array}{l}\text { Egypt's sacred historical } \\
\text { places in the video entice me. }\end{array}$ & 5.972 & 1.215 & 0.514 & -1.076 & 0.786 & & & \\
\hline $\begin{array}{l}\text { People and Cultures } \\
\text { portrayed in the video } \\
\text { fascinate me. }\end{array}$ & 5.964 & 1.175 & 0.783 & -1.086 & 0.757 & & & \\
\hline $\begin{array}{l}\text { Pharaoh Mummies and } \\
\text { Sphinxes in the video attract } \\
\text { my attention. }\end{array}$ & 5.949 & 1.284 & 1.039 & -1.264 & 0.763 & & & \\
\hline Egypt's ancient histories and & 6.059 & 1.199 & 1.369 & -1.345 & 0.773 & & & \\
\hline
\end{tabular}




\begin{tabular}{|c|c|c|c|c|c|c|c|c|}
\hline \multicolumn{9}{|l|}{$\begin{array}{l}\text { their mysteries portrayed, } \\
\text { provoke my curiosity to } \\
\text { explore. }\end{array}$} \\
\hline $\begin{array}{l}\text { Nile Cruises and Yachts in } \\
\text { the video catch my attention. }\end{array}$ & 5.821 & 1.309 & 0.494 & -1.049 & 0.727 & & & \\
\hline $\begin{array}{l}\text { Egypt's desert Safari (Camel } \\
\text { ride, Desert-camp nights, } \\
\text { etc.) shown, attracts my } \\
\text { interest. }\end{array}$ & 5.836 & 1.317 & 0.877 & -1.154 & 0.694 & & & \\
\hline $\begin{array}{l}\text { Night life and markets in the } \\
\text { video fascinate me. }\end{array}$ & 5.785 & 1.316 & 0.076 & -0.916 & 0.735 & & & \\
\hline $\begin{array}{l}\text { Egyptian Cuisine in the video } \\
\text { attracts my appetite. }\end{array}$ & 5.456 & 1.531 & -0.288 & -0.755 & 0.606 & & & \\
\hline \multicolumn{9}{|l|}{ Interest(INT) } \\
\hline I am closely tied with Egypt & 3.072 & 1.529 & -0.525 & 0.365 & 0.671 & \multirow[t]{3}{*}{0.628} & \multirow[t]{3}{*}{0.799} & \multirow[t]{3}{*}{0.572} \\
\hline $\begin{array}{l}\text { I feel glad when I think of } \\
\text { Egypt }\end{array}$ & 4.013 & 1.395 & -0.028 & -0.049 & 0.861 & & & \\
\hline $\begin{array}{l}\text { I am willing to learn } \\
\text { something related to Egypt } \\
\text { culture }\end{array}$ & 5.516 & 1.293 & -0.027 & -0.708 & 0.724 & & & \\
\hline \multicolumn{9}{|l|}{ I am closely tied with Egypt } \\
\hline Attitude (AT) & & & & & & & & \\
\hline $\begin{array}{l}\text { Visiting Egypt would be } \\
\text { relaxing to me }\end{array}$ & 4.860 & 1.314 & -0.109 & -0.290 & 0.838 & \multirow[t]{6}{*}{0.940} & \multirow[t]{6}{*}{0.953} & \multirow[t]{6}{*}{0.771} \\
\hline $\begin{array}{l}\text { Visiting Egypt would be } \\
\text { pleasant to me }\end{array}$ & 5.144 & 1.237 & -0.241 & -0.318 & 0.904 & & & \\
\hline $\begin{array}{l}\text { Visiting Egypt would be } \\
\text { fascinating to me }\end{array}$ & 5.537 & 1.211 & -0.336 & -0.528 & 0.872 & & & \\
\hline $\begin{array}{l}\text { Visiting Egypt would be } \\
\text { exciting to me }\end{array}$ & 5.629 & 1.201 & -0.033 & -0.682 & 0.882 & & & \\
\hline $\begin{array}{l}\text { I feel happy about visiting } \\
\text { Egypt }\end{array}$ & 5.309 & 1.266 & -0.049 & -0.459 & 0.920 & & & \\
\hline $\begin{array}{l}\text { I feel anticipating about } \\
\text { visiting Egypt }\end{array}$ & 5.213 & 1.331 & 0.109 & -0.505 & 0.849 & & & \\
\hline \multicolumn{9}{|l|}{ Subjective norms (SN) } \\
\hline $\begin{array}{l}\text { People who are important to } \\
\text { me agree that I should travel } \\
\text { to Egypt }\end{array}$ & 4.287 & 1.496 & -0.375 & -0.089 & 0.925 & \multirow[t]{4}{*}{0.943} & \multirow[t]{4}{*}{0.959} & \multirow[t]{4}{*}{0.854} \\
\hline $\begin{array}{l}\text { People who are important to } \\
\text { me support my decision to } \\
\text { travel to Egypt }\end{array}$ & 4.465 & 1.103 & -1.324 & 0.057 & 0.932 & & & \\
\hline $\begin{array}{l}\text { People who are important to } \\
\text { me understand I should } \\
\text { travel to Egypt }\end{array}$ & 4.258 & 1.487 & -0.318 & -0.076 & 0.924 & & & \\
\hline $\begin{array}{l}\text { People who are important to } \\
\text { me recommend that I travel } \\
\text { to Egypt }\end{array}$ & 4.118 & 1.596 & -0.505 & 0.003 & 0.917 & & & \\
\hline \multicolumn{9}{|l|}{$\begin{array}{l}\text { Positive anticipated emotion } \\
\text { (PAE) }\end{array}$} \\
\hline $\begin{array}{l}\text { If I travel to Egypt, I will be } \\
\text { excited }\end{array}$ & 5.742 & 1.164 & 0.048 & -0.703 & 0.917 & \multirow[t]{4}{*}{0.949} & \multirow[t]{4}{*}{0.963} & \multirow[t]{4}{*}{0.866} \\
\hline $\begin{array}{l}\text { If I travel to Egypt, I will be } \\
\text { glad }\end{array}$ & 5.552 & 1.270 & -0.432 & -0.526 & 0.943 & & & \\
\hline $\begin{array}{l}\text { If I travel to Egypt, I will be } \\
\text { satisfied }\end{array}$ & 5.348 & 1.333 & -0.073 & -0.518 & 0.921 & & & \\
\hline $\begin{array}{l}\text { If I travel to Egypt, I will be } \\
\text { happy }\end{array}$ & 5.539 & 1.249 & -0.464 & -0.481 & 0.942 & & & \\
\hline \multicolumn{9}{|l|}{$\begin{array}{l}\text { Negative anticipated } \\
\text { emotion (NAE) }\end{array}$} \\
\hline $\begin{array}{l}\text { If I can't travel to Egypt, I } \\
\text { will be angry }\end{array}$ & 2.586 & 1.442 & -0.347 & 0.597 & 0.836 & \multirow[t]{5}{*}{0.887} & \multirow[t]{5}{*}{0.919} & \multirow[t]{5}{*}{0.741} \\
\hline $\begin{array}{l}\text { If I can't travel to Egypt, I } \\
\text { will be disappointed }\end{array}$ & 3.266 & 1.711 & -0.810 & 0.347 & 0.896 & & & \\
\hline $\begin{array}{l}\text { If I can't travel to Egypt, I } \\
\text { will be worried }\end{array}$ & 2.488 & 1.486 & -0.071 & 0.780 & 0.806 & & & \\
\hline $\begin{array}{l}\text { If I can't travel to Egypt, I } \\
\text { will be sad }\end{array}$ & 3.136 & 1.716 & -0.771 & 0.401 & 0.902 & & & \\
\hline Perceived behavioral control & & & & & & & & \\
\hline
\end{tabular}




\begin{tabular}{|c|c|c|c|c|c|c|c|c|}
\hline (PBC) & & & & & & & & \\
\hline $\begin{array}{l}\text { I am confident that if I want, } \\
\text { I can travel to Egypt }\end{array}$ & 4.833 & 1.666 & -0.545 & -0.536 & 0.855 & \multirow[t]{4}{*}{0.826} & \multirow[t]{4}{*}{0.884} & \multirow[t]{4}{*}{0.657} \\
\hline $\begin{array}{l}\text { I am capable of traveling to } \\
\text { Egypt }\end{array}$ & 4.366 & 1.755 & -0.803 & -0.260 & 0.869 & & & \\
\hline $\begin{array}{l}\text { I have enough financial } \\
\text { resources to travel to Egypt }\end{array}$ & 3.608 & 1.866 & -1.050 & 0.174 & 0.787 & & & \\
\hline $\begin{array}{l}\text { I have enough time to travel } \\
\text { to Egypt }\end{array}$ & 3.851 & 1.837 & -1.043 & 0.081 & 0.725 & & & \\
\hline \multicolumn{9}{|l|}{ Desire (DE) } \\
\hline $\begin{array}{l}\text { I would like to travel to } \\
\text { Egypt in the near future }\end{array}$ & 5.074 & 1.619 & -0.380 & -0.607 & 0.937 & \multirow[t]{4}{*}{0.957} & \multirow[t]{4}{*}{0.969} & \multirow[t]{4}{*}{0.885} \\
\hline $\begin{array}{l}\text { I am excited about traveling } \\
\text { to Egypt in the near future }\end{array}$ & 4.924 & 1.626 & -0.563 & -0.466 & 0.962 & & & \\
\hline $\begin{array}{l}\text { I hope to travel to Egypt in } \\
\text { the near future }\end{array}$ & 5.113 & 1.619 & -0.288 & -0.651 & 0.939 & & & \\
\hline $\begin{array}{l}\text { I am eager to travel to Egypt } \\
\text { in the near future }\end{array}$ & 4.749 & 1.712 & -0.729 & -0.366 & 0.925 & & & \\
\hline \multicolumn{9}{|l|}{ Behavioral Intention (BI) } \\
\hline $\begin{array}{l}\text { I plan to travel to Egypt in } \\
\text { the near future }\end{array}$ & 4.596 & 1.747 & -0.843 & -0.300 & 0.906 & \multirow[t]{4}{*}{0.914} & \multirow[t]{4}{*}{0.940} & \multirow[t]{4}{*}{0.796} \\
\hline $\begin{array}{l}\text { I will make an effort to travel } \\
\text { to Egypt in the near future }\end{array}$ & 5.204 & 1.456 & 0.246 & -0.751 & 0.846 & & & \\
\hline $\begin{array}{l}\text { I have an intention to travel } \\
\text { to Egypt in the near future }\end{array}$ & 4.363 & 1.804 & -0.955 & -0.156 & 0.896 & & & \\
\hline $\begin{array}{l}\text { I am willing to travel to } \\
\text { Egypt in the near future }\end{array}$ & 4.427 & 1.761 & -0.823 & -0.211 & 0.919 & & & \\
\hline
\end{tabular}

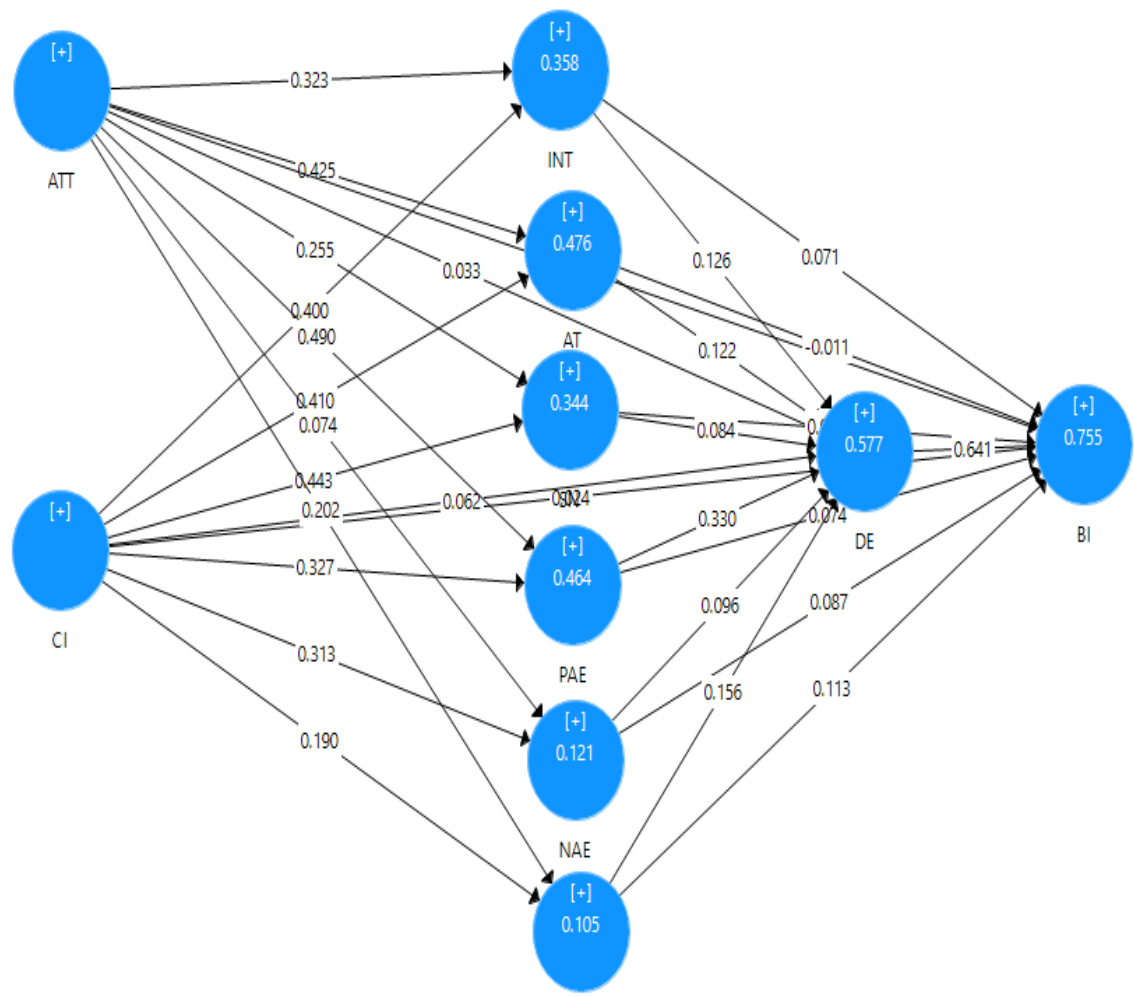

$\mathrm{PBC}$

Fig 2: The research model with the path- values of all direct and indirect relations and R2 values

To assess the discriminant validity, FornellLarcker criterion and HTMT were analyzed and the findings portrayed acceptable measurement model's discriminant validity (Steenkamp \& Trijp, 1991).
Figure 2 shows all direct and indirect pathvalues along with $\mathrm{R}^{2}$ values. Focusing on $f^{2}$, both CI and ATT were shown to have medium effects on AT $\left(f^{2}=0.278\right)$ and $\left(f^{2}=0.298\right)$, respectively. ATT was shown to have small effect on INT $\left(f^{2}=0.141\right)$, SN $\left(f^{2}=0.086\right)$ and 
PBC $\left(f^{2}=0.039\right)$. Interestingly ATT was shown to have a large effect on PAE $\left(f^{2}=.388\right)$

\subsection{Hypothesis Testing}

The result showed that $\mathrm{CI}$ significantly and positively influences AT $\left(\beta_{\mathrm{CI} \rightarrow \mathrm{AT}}=0.410, \mathrm{t}=\right.$ 12.751), supporting H1. ATT positively and significantly effects INT $\left(\beta_{\mathrm{ATT} \rightarrow \mathrm{INT}}=0.324\right.$, $\mathrm{t}=7.997), \mathrm{AT}\left(\beta_{\mathrm{ATT} \rightarrow \mathrm{AT}}=0.426, \mathrm{t}=11.939\right), \mathrm{SN}$ $\left(\beta_{\mathrm{ATT} \rightarrow \mathrm{SN}}=0.255, \mathrm{t}=6.911\right), \operatorname{PAE}\left(\beta_{\mathrm{ATT} \rightarrow \mathrm{PAE}}=\right.$ $0.493, \mathrm{t}=15.115)$ and $\mathrm{PBC}\left(\beta_{\mathrm{ATT} \rightarrow \mathrm{PBC}}=0.203, \mathrm{t}=\right.$ 4.734), and thus H2-1, H2-2, H2-3, H2-4, H2-5, are being supported with $p<0.001$. INT positively and significantly influences DE $\left(\beta_{\mathrm{INT} \rightarrow \mathrm{DE}}=0.130, \mathrm{t}=2.798\right)$, and hence $\mathrm{H} 3$ was supported with $p<0.01$. DE and $\mathrm{BI}\left(\beta_{\mathrm{DE} \rightarrow \mathrm{BI}}=\right.$ $0.642, \mathrm{t}=20.341)$ were also found to be positively and significantly correlated, thus supporting $\mathrm{H} 4$ with $p<0.001$. Moreover, AT $\left(\beta_{\mathrm{AT} \rightarrow \mathrm{DE}}=0.120, \mathrm{t}=2.154\right), \mathrm{SN}\left(\beta_{\mathrm{SN} \rightarrow \mathrm{DE}}=0.081, \mathrm{t}\right.$ $=1.976), \operatorname{PAE}\left(\beta_{\mathrm{PAE} \rightarrow \mathrm{DE}}=0.330, \mathrm{t}=6.097\right), \mathrm{NAE}$ $\left(\beta_{\mathrm{NAE} \rightarrow \mathrm{DE}}=0.097, \mathrm{t}=3.199\right)$ and $\mathrm{PBC}\left(\beta_{\mathrm{PBC} \rightarrow \mathrm{DE}}=\right.$ $0.157, \mathrm{t}=4.842)$, were proved to have positive and significant correlation with $\mathrm{DE}$, and hence supporting the hypotheses $\mathrm{H} 5$ and $\mathrm{H} 6$, with $p$ $<0.05$ and H7, H8 and H9-1 with $p<0.001$, respectively. Additionally, $\mathrm{PBC}$ positively and significantly influences $\mathrm{BI}\left(\beta_{\mathrm{PBC} \rightarrow \mathrm{BI}}=0.113, \mathrm{t}=\right.$ 3.767, ), supporting H9 with $p>0.001$.

\section{DISCUSSIONS}

The results mostly supported earlier researches, especially the portion of relations, adapted from the study by Lee et al., 2018 (Lee et al., 2018; Song et al., 2012). Focusing on the added variable first, country image positively and significantly relates with attitude towards the destination, which means that a positive change in country image creates positive attitude towards the destination, and vice versa. This is consistent with Philip et al., (2013) study, where the country image affects the attitude towards the behavioural intention. It also supports Laroche et al., (2005) and Roth \& Diamantopoulos, (2009), who stated that the country image is capable of influencing customer attitudes regarding the goods of a particular destination. However not many studies particularly mentioned about changing the attitudes in respect to risky destinations, and hence making it an addition to the related literatures.

Some interesting findings came up by employing the adapted integrated model. Unlike the Lee et al., (2018) study, attitude towards the destination had positively and significantly influences desire to visit risky destinations. This is consistent with Lee et al., (2020) study who found that attitude have positive influence on desire toward heritage tourism destinations visiting. In addition, PBC also significantly and positively related with behavioural intention, which is supported by Gstaettner et al., (2017) study, where they found that it was positively related to motivation to accomplish a behaviour. Moreover, attention towards destination attributes shown in the Egypt's ODPV, positively influenced prospective young tourists' overall emotions, interests, attitudes, desires and behaviours toward visiting Egypt (Whang, Yong, \& Ko 2016). The AIDA model variables' relations of (attention, interest, desire \& actions) are supported by Lee et al., (2018) study.

The MGB explained additional elements that create destination intentions and desires to travel to the place. Like some past literatures (Lee et al., 2018; Song et al., 2012), AT, SN, PAE, NAE and PBC, performed positive and significant parts in creating respondents' desires (DE) to visit Egypt, which aided them for decision-making intentions to travel to a risky destination like Egypt. In respect to PAE, this suggests that respondents' positive emotional reactions concerning Egypt are critical in creating desire to travel to Egypt, which is supported by Lee et al., (2018) and Kim et al., (2012) who stated that tourists get encouraged by high hopes for satisfaction or excitement in their trips. Moreover, the positive and significant relations between $\mathrm{PBC}$ and desire to travel to Egypt, is supported by Yi, Yuan \& Yu (2020) study, where PBC positively relates with desire. Subjective norms created a positive impact in creating a desire to travel to risky place like Egypt, and is supported by past literatures (Lee et al., 2018, 2020). The findings confirmed the MGB and AIDA models as valid in explaining and assessing the prospective young tourists' decision-making process towards visit risky destinations (Lee et al., 2018).

\subsection{Theoretical \& Practical Implications}

The development of an extensive model with addition of country image construct, to the adapted integrated model, for a more detailed assessment of ODPV and country image influences on the complex decision-making 
processes of tourists in travelling to risky destinations, creates a contribution to the related literatures. According to the researcher knowledge, the relation of country image along with the elements of AIDA and MGB in an integrated model, on the decision-making intention to risky destination, in such an extensive way, had not being investigated earlier. Findings further identified AIDA model to be an effective model in assessing ODPVs in correlation studies in risky destination tourism context. It is believed that this research is the one of the very few studies which assessed the "causal relationships" amongst AIDA's constructs in tourism context, but can be the first study in relation with ODPV of risky destination, along with country image.

The results would help and guide DMOs to monitor the social media's ODPV's contents, and encourage and uphold the interest in the country by portraying its attributes in the online ODPVs, and recognize how much the country image is related with decision-making behavior. This might enhance the prospective young tourists' emotional ties to the country through the ODPVs, thus igniting their interest and desire to visit such risky destinations, and improve country image and their tourism sectors. Moreover, the results can also help future related researches.

\subsection{Limitations and Future Implications}

The present research emphases on young tourists from Malaysia only with varied nationality. Results might vary if focused on different-aged tourists or on a particular nationality. Another limitation was that, this study was conducted in pandemic times, where travelling was itself was banned and a fear of getting infected was always there, hence everyone was physically and psychologically affected which might create some effects on the outcomes of the study. Data was collected through online due to pandemic, as it was forbidden to meet any one face to face because of the possibility of transmission. So, the accuracy of the data collected remains a bit indistinct, which means whether the respondents had seen the video fully or not before answering the questionnaire, remains unclear. Factors like viewers' trust, source credibility, or popularity level of ODPV, may help future researchers to further understand their contribution in improving country image, thus improving attitude towards the destination and visiting intention.

\section{CONCLUSION}

This study provides an extensive understanding and prediction of future complex decision-making behavioral processes through country image and ODPV to make a visiting intention to a risky destination, and can be a good reference to the young tourists, DMOs and future researchers.

\section{REFERENCES}

Ajzen,I. (1991).The theory of planned behavior. Organizational Behavior and Human Decision Processes.50 (2):179-211.

Alvarez, M. D., \& Martínez, S. C (2010). Country versus destination image in a developing country. Journal of Travel $\mathcal{E}$ Tourism Marketing, 27(7), 748-764.

Alvarez, M.D., \& Campo,S.(2014).The influence of political conflicts on country image and intention to visit: A study of Israel's image. Tourism Management,40,70-78.

Andrews, M., \& Kim, D. (2007). Revitalising suffering multinational brands: An empirical study. International Marketing Review, 24(3), 350-372.

Assante, L. M., Sukalakamala, S., Wen, H. I., \& Knudson, D. A. (2014). Identifying optimal communication mix for strategic destination image formation: A case study of Austria. Journal of Management and Marketing Research, -, 1-15.

Barcelos, R. H., Dantas, D. C., \& Sénécal, S. (2019). The tone of voice of tourism brands on social media: Does it matter?. Tourism management, 74, 173-189.

Brodien Hapairai, P.M. ,Walters,G., \& Li,S. (2018).The effectiveness of ad-induced emotion in reducing tourist risk perceptions towards politically unstable destinations. Tourism Recreation Research,1-14.

Campo, S., \& Alvarez, M. D. (2010). Country versus destination image in a developing country. Journal of Travel \& Tourism Marketing, 27(7), 749e765

Carrus,G.,Passafaro,P.,\& Bonnes,M.(2008).Emotions,habits and 
rational choices in ecological behaviours:The case of recycling and use of public transportation. Journal of environmental psychology,28(1),51-62.

Chen, P. J., Hua, N. ,Shani, A., \& Wang, Y., (2010). Testing the impact of a promotional video on destination image change: Application of China as a tourism destination. International Journal of Tourism Research, 12(2), 116-133

Dolnicar,S.,\& Hajibaba,H.,(2015).What drives trip cancellations when a disaster hits? CAUTHE 2015:Rising Tides and Sea Changes:Adaptation and Innovation in Tourism and Hospitality,155.

Elliot, S., Papadopoulos, N., \& Kim, S. S. (2011). An integrative model of place image: Exploring relationships between destination, product, and country images. Journal of Travel Research, 50(5), 520-534.

Fong,Y.L.,Firoz,D.,\&

Sulaiman,W.I.W.(2018).The impact of tourism advertisement promotional videos on young adults.e-Bangi,12(3).

Fornell, C., \& Larcker, D.F. (1981). Evaluating structural equation models with unobservable and measuremenr error Journal of Marketing Research, 34(2), 161188.

Gong, T., \& Tung, V. W. S. (2017). The impact of tourism mini-movies on destination image: The influence of travel motivation and advertising disclosure. Journal of travel E tourism marketing, 34(3), 416-428.

Gray, J., C. Sandvoss, \& C. L. Harrington. 2007. Fandom: Identities and Communities in a Mediated World. New York: New York University Press

Gstaettner, A. M., Rodger, K., \& Lee, D. (2017). Visitor perspectives of risk management in a natural tourism setting: An application of the Theory of Planned Behaviour. Journal of Outdoor Recreation and Tourism, 19(October 2016), 1-10.

Hajibaba,H.,Gretzel,U.,Leisch,F., \& Dolnicar,S.(2015).Crisis-resistant tourists. Annals of Tourism Research,53,46-60.

Han,H.,\& H.J.Yoon.(2015).Hotel customers' environmentally responsible behavioral intention:Impact of key constructs on decision in green consumerism.
International Journal of Hospitality Management 45:22-33.

Hendriana, E., Awang, K. W., \& Yusof, R. N. R. (2021). The roles of the country's cognitive, affective, and personality aspects in international students' decision-making. Journal of Marketing for Higher Education, 1-18.

Huang, S., \& Hsu, C. H. (2009). Effects of travel motivation, past experience, perceived constraint, and attitude on revisit intention. Journal of travel research, 48(1), 29-44.

Huang, S., \& van der Veen, R. (2018). The moderation of gender and generation in the effects of perceived destination image on tourist attitude and visit intention: A study of potential Chinese visitors to Australia. Journal of Vacation Marketing, 1356766718814077

Hudson,S.,Wang,Y.,\& Gil,S. M.(2011).The influence of a film on destination image and the desire to travel: A cross-cultural comparison. International journal of tourism research,13(2),177-190.

Huertas,A.,Míguez-González,M.I.,\& LozanoMonterrubio, N.(2017). YouTube usage by Spanish tourist destinations as a tool to communicate their identities and brands. Journal of Brand Management,24(3),211-229.

Hyder, S., Khan, A., Nawaz, T. \& Rehman, F. (2014). How advertising affects the buying behavior of consumers in rural areas: a case of Pakistan. Academic Research International, 5.

Ibrahim, S. E. (2015). Egypt's socio-political profile revisited. The International Spectator, 50(4), 75-79.

Itoo, M. H., \& Nagar, K. (2017). Impact of negative portrayal of a destination in bollywood movies on viewers' attitude towards the destination, intention to visit and destination image. Pacific Business Review International, 10(5), 71-82.

Itoo, M. H., \& Nagar, K. (2019). Audience Responses Towards Positive and Negative Destination Placement in Films: An Experimental Investigation. International Journal of Hospitality and Tourism Systems, 12(1), 73. 
Karyotakis,M.A.,Antonopoulos,N.,Veglis,A.,\& Kiourexidou,M.(2018).Tourist go home: communication and propaganda on YouTube. Journal of Media Critiques [JMC],4(14).

Kim, H., \& Richardson, S. L. (2003). Motion picture impacts on destination images. Annals of tourism research, 30(1), 216-237.

Kim, J. S., Lee, T. J., \& Kim, N. J. (2021). What motivates people to visit an unknown tourist destination? Applying an extended model of goal-directed behavior. International Journal of Tourism Research, 23(1), 13-25.

Kim, M. J., Lee, M. J., Lee, C. K., \& Song, H. J. (2012). Does gender affect Korean tourists' overseas travel? Applying the model of goal-directed behavior. Asia Pacific Journal of Tourism Research, 17(5), 509-533.

Kim, S. H., Lee, K., \& Fairhurst, A. (2017). The review of "green" research in hospitality, 2000-2014: Current trends and future research directions. International Journal of Contemporary Hospitality Management, 29(1), 226-247.

Kim,S.(2012).Audience involvement and film tourism experiences: Emotional places, emotional experiences.Tourism Management,33(2),387-396.

Kumar, P., Mishra, J. M., \& Rao, Y. V. (2021). Analysing tourism destination promotion through Facebook by Destination Marketing Organizations of India. Current Issues in Tourism, 1-16.

Laroche,M.,Papadopoulos,N.,Heslop,L. A.,\& Mourali,M.(2005).The influence of country image structure on consumer evaluations of foreign products.International Marketing Review,22(1),96e115.

Lee, C. K., Ahmad, M. S., Petrick, J. F., Park, Y. N., Park, E., \& Kang, C. W. (2020). The roles of cultural worldview and authenticity in tourists' decision-making process in a heritage tourism destination using a model of goal-directed behavior. Journal of Destination Marketing \& Management, 18, 100500.
Lee, S.,Song,H.,Lee,C. K.,\& Petrick,J.F.(2018).An Integrated Model of Pop Culture Fans' Travel Decision-Making Processes. Journal of Travel Research,57(5),687-701

Lee,C.K.,Song,H. J.,Bendle,L.J.,Kim,M.J.,\& Han,H.S.(2012).The impact of nonpharmaceutical interventions for 2009 H1N1 influenza on travel intentions: a model of goal-directed behavior.Tourism Management,33(1),89e99.

Lee,J.,Pan,S.\& Tsai,H.(2011).Framing New Zealand: Understanding tourism TV commercials,Tourism Management,32,596603

Leone,L.,M.Perugini,\&

A.P.Ercolani (2004).Studying, practicing, and mastering: a test of the model of goaldirected behavior (MGB) in the software learning domain. Journal of Applied Social Psychology,34(9):1945-73.

Li, M., Cai, L. A., \& Qiu, S. (2016). A value, affective attitude, and tourist behavioral intention model. Journal of China Tourism Research, 12(2), 179-195.

Lindblom, A., Lindblom, T., Lehtonen, M. J., \& Wechtler, H. (2018). A study on country images, destination beliefs, and travel intentions: A structural equation model approach. International Journal of Tourism Research, 20(1), 1-10.

Lu, I. R., Heslop, L. A., Thomas, D. R., \& Kwan, E. (2016). An examination of the status and evolution of country image research. International Marketing Review, 33(6), 825850.

Maher,A.A., \& Carter,L. L.(2011).The affective and cognitive components of country image. Perceptions of American products in Kuwait. International Marketing Review,559-580.

Meng, B., \& Choi, K. (2016). The role of authenticity in forming slow tourists' intentions: Developing an extended model of goal-directed behavior. Tourism Management, 57, 397-410.

Neuburger, L., \& Egger, R. (2021). Travel risk perception and travel behaviour during the COVID-19 pandemic 2020: A case study of the DACH region. Current Issues in Tourism, 24(7), 1003-1016. 
Park,E.,Lee,S., ～\& Peters,D.J.(2017).Iowa wetlands outdoor recreation visitors' decision-making process: An extended model of goal-directed behavior. Journal of Outdoor Recreation and Tourism,17,64-76.

Pennacchia,M.(2015).Adaptation-induced tourism for consumers of literature on screen: the experience of Jane Austen fans. Almatourism-Journal of Tourism, Culture and Territorial Development,6(4),261-268.

Perugini, M., \& Conner, M. (2000). Predicting and understanding behavioral volitions: The interplay between goals and behaviors. European Journal of Social Psychology, 30(5), 705-731.

Perugini,M., \& Bagozzi,R.P.(2001).The role of desires and anticipated emotions in goaldirected behaviours: Broadening and deepening the theory of planned behaviour. British Journal of Social Psychology,40(1),79-98.

Phillips, W. J., Asperin, A., \& Wolfe, K. (2013). Investigating the effect of country image and subjective knowledge on attitudes and behaviors: US Upper Midwesterners' intentions to consume Korean Food and visit Korea. International Journal of Hospitality Management, 32, 49-58.

Prestwich,A.,Perugini,M.,\& Hurling,R.(2008).Goal desires moderate intention behaviour relations. British Journal of Social Psychology,47(1),49e71.

Rawal,P.(2013).AIDA marketing communication model: Stimulating a purchase decision in the minds of the consumers through a linear progression of steps. IRC's International Journal of Multidisciplinary Research in Social $\mathcal{E}$ Management.1, 37-44.

Roth, K., \& Diamantopoulos, A. (2009). Advancing the country image construct. Journal of Business Research, 62(7), 726740 .

Shani,A.,Chen,P.J.,Wang,Y., \& \& Hua,N.(2010).Testing the impact of a promotional video on destination image change: Application of China as a tourism destination. International Journal of Tourism Research,12(2),116-133.

Song, H., Ruan, W. J., \& Jeon, Y. J. J. (2021). An integrated approach to the purchase decision making process of fooddelivery apps: Focusing on the TAM and AIDA models. International Journal of Hospitality Management, 95, 102943.

Song,H.,You,G. J.,Reisinger,Y.,Lee,C.K., ～\& Lee,S.K.(2014).Behavioral intention of visitors to an oriental medicine festival: An extended model of goal directed behavior. Tourism Management,42:10113.

Song, H.J., Lee, C.K., Kang, S.K., \& Boo, S.J. (2012).The effect of environmentally friendly perceptions on festival visitors' decision-making process using an extended model of goal-directed behavior. Tourism Management, 33(6), 1417-1428.

Sousa,A., \& Silva,J. (2018).Text worlds in interplay: The rhetoric of film induced tourism. Revista Turismo \& Desenvolvimento,2(27/28),447-449.

Steenkamp, J. B. E., and H. C. Van Trijp. 1991. "The Use of LISREL in Validating Marketing Constructs." International Journal of Research in Marketing 8 (4): 283-99.

Syafganti, I., \& Walrave, M. (2019). Promoting a risky destination image: Assessing Indonesia's official tourism website. $e$ Review of Tourism Research, 16(6).

Taylor,D.G.,Lewin,J.E., \& \& Strutton,D.(2011).Friends, Fans, and Followers: Do Ads Work on Social Networks? Journal of Advertising Research,51(1),258-275.

Teixeira, J.E.M. (2017).The role of promotional touristic videos in the creation of visit intent to Barcelona. International journal of scientific management and tourism,3(1),463490.

Tham, A., \& Kim, S. (2018).Factors hindering the intention of tourists to visit film tourism locations: The case of the Korean TV drama Descendants of the Sun (DOTS). In Film Tourism in Asia (pp.157170).Springer,Singapore.

Tiago, F., Moreira, F., \& Borges-Tiago, T. (2019). YouTube Videos: A Destination Marketing Outlook. In Strategic Innovative 
Marketing and Tourism (pp. 877-884). Springer, Cham.

UNWTO Annual Report 2017. (2018). https://www.eunwto.org/doi/book/10. 18111/9789284419807

Uşaklı, A., Koç, B., \& Sönmez, S. (2017). How'social'are destinations? Examining European DMO social media usage. Journal of destination marketing $\mathcal{E}$ management, 6(2), 136-149.

Walters, G., \& Beirman, D. (2017). 12. Marketing the Middle East in Times of Political Instability-The Case of Jordan. In Tourism in the Arab World (pp. 175-187). Channel View Publications.

Wang, S. (2020). An inquiry into country image components and their effects on perceived destination image and travel intentions. Tourism Recreation Research, 112.

Wang, X., Chow, C. W., \& Yang, Z. (2012). A two-path model on the effects of positivity and empathy reflected by online reviews: a choice mechanism perspective. International Journal of Internet Marketing and Advertising, 7(3), 260-277.

Whang, H., Yong, S., \& Ko, E. (2016). Pop culture, destination images, and visit intentions: Theory and research on travel motivations of Chinese and Russian tourists. Journal of business research, 69(2), 631-641.
Wijaya, B.S.(2015).The development of hierarchy of effects model in advertising. International Research Journal of Business Studies,5(1).

World Travel and Tourism Council (2018) Economic Impact 2018 Egypt

Yanjun, X., Tian,M., \& Yindong,W.(2014).An Empirical Research on Destination Image Change of Promotional Videos, OnlineReviews and Travel Notes--A Case study for the Change of Taiwan's Image. Journal of Beijing International Studies University,36(1),77.

Yi, J., Yuan, G., \& Yoo, C. (2020). The effect of the perceived risk on the adoption of the sharing economy in the tourism industry: The case of Airbnb. Information Processing \& Management, 57(1), 102108.

Zeng,S., Chiu,W., Lee,C.W., Kang,H.W., \& Park,C.(2015).South Korea's destination image: Comparing perceptions of film and nonfilm Chinese tourists. Social Behavior and Personality: an international journal,43(9),1453-1462.

Zhang, J.,Wu, B., Morrison,A.M.,Tseng,C., \& Chen,Y.C.(2018).How country image affects tourists' destination evaluations: A moderated mediation approach. Journal of Hospitality $\mathcal{E}$ Tourism Research,42(6),904930 